\title{
Organic matter release by the dominant primary producers in a Caribbean reef lagoon: implication for in situ $\mathrm{O}_{2}$ availability
}

\author{
Andreas F. Haas ${ }^{1, *}$, Carin Jantzen ${ }^{1,2}$, Malik S. Naumann1, Roberto Iglesias-Prieto ${ }^{3}$ \\ Christian Wild ${ }^{1}$ \\ ${ }^{1}$ Coral Reef Ecology (CORE) Work Group, GeoBio-Center and Department of Earth \& Environmental Science, \\ Ludwig-Maximilians Universität, Richard Wagner Strasse 10, 80333 Munich, Germany \\ ${ }^{2}$ Centre for Tropical and Marine Ecology (ZMT), Bremen, Germany \\ ${ }^{3}$ Reef Systems Unit, Instituto de Ciencias del Mar y Limnologia, Universidad Nacional Autónoma de México, \\ Apartado Postal 1152, Cancún QR 77500, Mexico
}

\begin{abstract}
Coral reef lagoon benthic primary producers may control various processes important for ecosystem functioning, predominately via the release of organic matter, but comparative data are rare. This study therefore comparatively investigated the quantity of particulate and dissolved organic matter released by different benthic primary producers (seagrasses, macroalgae and scleractinian corals) from the coral reef lagoon of Puerto Morelos, Mexican Caribbean. Microbial degradability of the released organic matter was determined along with diurnal in situ measurements of $\mathrm{O}_{2}$ concentrations at lagoon sites dominated by different primary producers. Particulate organic carbon (POC) release was highest for corals $\left(8.2 \pm 4.2 \mathrm{mg} \mathrm{m}^{-2} \mathrm{~h}^{-1}\right)$, followed by benthic algae $(3.9 \pm 0.7 \mathrm{mg}$ $\left.\mathrm{m}^{-2} \mathrm{~h}^{-1}\right)$ and seagrasses $\left(3.1 \pm 2.0 \mathrm{mg} \mathrm{m}^{-2} \mathrm{~h}^{-1}\right)$. Dissolved organic carbon (DOC) release rates were highest for seagrasses $\left(15.8 \pm 6.0 \mathrm{mg} \mathrm{m}^{-2} \mathrm{~h}^{-1}\right)$, followed by algae $\left(1.9 \pm 2.0 \mathrm{mg} \mathrm{m}^{-2} \mathrm{~h}^{-1}\right)$, whereas corals displayed net DOC uptake. Benthic algae-derived organic matter stimulated planktonic microbial $\mathrm{O}_{2}$ consumption significantly more than seagrass- or coral-derived organic matter. In situ $\mathrm{O}_{2}$ loggers revealed significantly lower average $\mathrm{O}_{2}$ concentrations, particularly during the night, at algae-dominated sites compared to other benthic lagoon environments. This indicates effects of algae-derived organic matter on in situ $\mathrm{O}_{2}$ availability. We therefore suggest that shifts in benthic primary producer dominance affect ecosystem functioning owing to differences in quantity, composition and microbial degradability of the released organic matter.
\end{abstract}

KEY WORDS: Organic matter $\cdot$ Primary producer $\cdot$ Caribbean reef lagoon $\cdot$ Oxygen $\cdot$ Coral $\cdot$ Algae $\cdot$ Seagrass

Resale or republication not permitted without written consent of the publisher

\section{INTRODUCTION}

Caribbean coral reef lagoons typically accommodate different species of seagrasses, macroalgae and scleractinian corals (Williams 1987, Nagelkerken et al. 2000). These lagoon ecosystems are highly productive, with rates of primary production similar to those of coral reef ecosystems (Odum et al. 1959, Odum 1971). High associated biomass, productivity and turnover of organic material can serve as a reservoir for complex food chains (Ogden \& Zieman 1977, Ziegler \& Benner 1999). Caribbean coral reef lagoons thereby provide organic compounds derived from primary producers as resources for fish and invertebrates. Contrary to coral reef ecosystems, which usually display close linkage between trophic levels relevant for element recycling processes (Lesser 2004), reef lagoons display more open nutrient cycles (Ogden \& Zieman 1977). Therefore, primary producer-derived organic compounds may even be exported to adjoining ecosystems (Jack- 
son et al. 2001), where they serve as a substantial supply in oligotrophic environments (Suchanek et al. 1985, Lapointe et al. 2005).

Tropical reef lagoon-associated benthic communities are structurally and functionally complex (Biber et al. 2004) and thus particularly susceptible to environmental changes (Fonseca et al. 2000, Kendrick et al. 2000, Eyre \& Ferguson 2002). The typical lagoon community response to environmental disturbances (e.g. nutrient enrichment, terrestrial run offs, changes in herbivore abundance) is a sequential change in the dominance of primary producers (Nienhuis 1992, Castel et al. 1996, Raffaelli et al. 1998). Those primary producers, partly via their ability to influence the environment by the release of organic matter (Costanza et al. 1997, Hemminga \& Duarte 2000, Wild et al. 2004a), represent the basis of the food chain of reef lagoons and adjoining ecosystems.

Organic matter released by different marine primary producers may thereby affect activity and growth of microbial communities, which in turn play an important role in the transfer of energy to higher trophic levels (Tenore 1977, Azam et al. 1994, Ferrier-Pages et al. 2000, Eyre \& Ferguson 2002, Wild et al. 2004a, Wild et al. 2005). The effects of the released organic matter on the microbial community can significantly differ between primary producing organisms (Wild et al. 2009). For example, coral-derived organic matter in the form of mucus can function as an important energy and nutrient carrier in benthic-pelagic coupling processes (Wild et al. 2004b, Naumann et al. 2010). Thereby, it may influence planktonic as well as benthic microbial metabolism (Wild et al. 2005, Huettel et al. 2006). Such complex functions are likely not substituted by reefassociated benthic algae-derived organic matter (Wild et al. 2009). Laboratory studies (Kline et al. 2006, Smith et al. 2006) have further indicated that benthic reef algae may affect processes, such as microbial activity, by the release of more labile dissolved organic matter (DOM) compared to corals. The faster heterotrophic utilisation of algae-derived organic matter may then influence planktonic $\mathrm{O}_{2}$ dynamics (Eyre \& Ferguson 2002), potentially leading to $\mathrm{O}_{2}$ deficiency with critical consequences for some ecosystem inhabitants (Kline et al. 2006, Smith et al. 2006).

Phase shifts in the primary producer community of reef lagoons could, therefore, cause changes in cycles of matter (Eyre \& Ferguson 2002), benthic and planktonic degradation and, therefore, $\mathrm{O}_{2}$ availability. The best way to understand these changes is to characterise the organic matter (e.g. quantity, chemical composition and degradability) released by the different primary producers and its influence on the microbial community. A very recent study by Wild et al. (2009) comparatively investigated these interactions for a fringing coral reef ecosystem in the Northern Red Sea. However, not much is known about the organic matter released by primary producers in coral reef lagoon systems (reviewed by Kaldy et al. 2002) and its contribution to ecosystem functioning (Ziegler \& Benner 1999). Only a few studies have investigated the production of organic matter relative to benthic community composition in tropical lagoon systems (Brylinsky 1977, Kirkman \& Reid 1979, Ziegler \& Benner 1999), and no study has carried out a comparative investigation into the related effects on microbial activity. The present study therefore aims to give a comprehensive overview of organic matter release by the dominant primary producers in a typical Caribbean reef lagoon and its subsequent influence on the activity of the planktonic microbial community as well as in situ $\mathrm{O}_{2}$ availability.

\section{MATERIALS AND METHODS}

Study site. The study was conducted at the Institute of Marine Sciences and Limnology (ICML, 20 $52^{\circ} \mathrm{N}$, $86^{\circ} 52^{\prime}$ E) of the National Autonomous University of Mexico (UNAM) in Puerto Morelos, Mexico, from 15 July to 7 August 2008. An extensive coral reef lagoon is located alongside the ICML and is bordered on the seaward side by the north-south orientated Mesoamerican barrier reef system (Fig. 1). Jordan et al. (1981) divided this reef system into front and rear reef, reef crest and reef lagoon. The reef lagoon extends from the coastline to the barrier reef that runs diagonally at a distance of $1500 \mathrm{~m}$ in the north and 200 to 300 $\mathrm{m}$ close to Puerto Morelos village. Mean water currents inside the lagoon are $0.1 \mathrm{~m} \mathrm{~s}^{-1}$ directed to the north, as recorded by previous studies of Coronado et al. (2007) and Merino-Ibarra \& Otero-Dávalos (1991), and the mean water residence time in the lagoon is about $3 \mathrm{~h}$ (Coronado et al. 2007). The maximum water depth is $4 \mathrm{~m}$ in the central lagoon. The seafloor of the lagoon consists mostly of calcareous sand, which is covered by seagrass meadows (Collado-Vides 1998) with occasional algae, and soft and hard coral patches.

Environmental parameter monitoring. Previous studies have shown that environmental parameters have considerable influence on organic matter release by benthic organisms (Ziegler \& Benner 1999, Naumann et al. 2010, Haas et al. 2010). Therefore, temperature and light availability were recorded during the whole study period. Both parameters were measured in triplicate within a radius of $10 \mathrm{~m}$, using light and temperature loggers (Onset HOBO ${ }^{\circledR}$ Pendant UA-00264) with a 1 min temporal resolution and in water depths of $3 \mathrm{~m}$. To allow for better comparability with previous studies, light intensities (lx), were converted to photosynthetically active radiation (PAR, $\mu \mathrm{mol}$ 


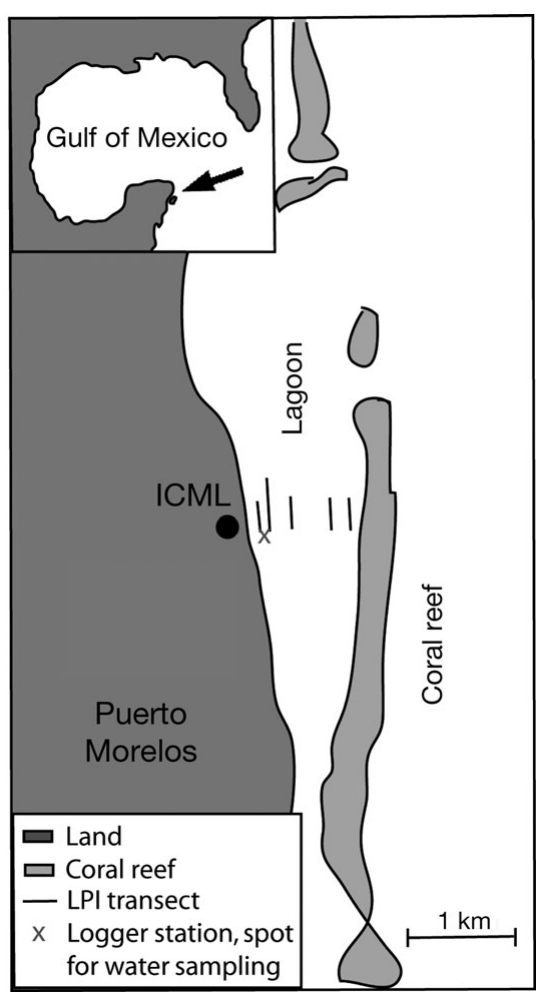

Fig. 1. The study area indicating line point intercept (LPI) transect locations, and the site for light and temperature measurements and water sampling. ICML: Institute of Marine Sciences and Limnology

quanta $\mathrm{m}^{-2} \mathrm{~s}^{-1}, 400$ to $700 \mathrm{~nm}$ ). This was done using the following approximation: $1 \mu \mathrm{mol}$ quanta $\mathrm{m}^{-2} \mathrm{~s}^{-1}=51.2$ lx (Valiela 1984).

Benthic community assessment. To identify the dominant benthic organisms and their relative seafloor cover, 12 line point intercept transects (LPI, Hodgson et al. 2004) were conducted. Water depths, surveyed distances and distances to shore of each LPI were measured (see Table 1). Benthic cover, including all occurring genera of scleractinian corals (Manicina, Porites), seagrasses (Thalassia, Syringodium), dominant green algae (Avrainvillea, Halimeda, Rhipocephalus, Penicillus), and other green-, red- and brown algae as well as sand as substrate, were recorded at $0.5 \mathrm{~m}$ intervals directly below the measurement point and marked on a dive slate. LPI data were then analysed to derive the percentage coverage for the respective benthic organisms or substrate.

Collection of specimens. Two seagrass, 6 benthic algae and 2 coral genera, together amounting to $56.9 \pm$ $6.0 \%$ of the total lagoon seafloor coverage and $92.6 \pm$ $2.8 \%$ of all benthic macroorganism coverage, were selected for incubation experiments. Coral specimens of the genus Porites were further investigated in bleached and unbleached conditions (see Table 2).
Specimens ( $\mathrm{N}=5$ for each species or bleaching condition) were collected from individual colonies using SCUBA and transferred to cultivation tanks without air exposure. Cultivation tanks (200 l) were provided with fresh seawater flow-through (exchange rate: 150 to $200 \mathrm{l} \mathrm{h}^{-1}$ ). In situ temperature and light conditions were verified by light and temperature logger (Onset HOBO ${ }^{\circledR}$ Pendant UA-002-64) measurements.

To avoid leakage of intracellular organic matter due to potential injuries from the sampling procedure, seagrass (12 to $26 \mathrm{~cm}$ height) and algal specimens (5 to $12 \mathrm{~cm}$ height) were sampled at least $48 \mathrm{~h}$ before the respective incubation experiment and left to heal in the cultivation tank.

Porites colonies and individual Manicina polyps (diameter: 3 to $9 \mathrm{~cm}$ ) were sampled $1 \mathrm{wk}$ prior to incubation experiments and fixed onto ceramic tiles $(4 \times$ $4 \mathrm{~cm}$ ) using small amounts of coral glue (Reef Construct, Aqua Medic ${ }^{\circledR}$ ), in such a way that only living coral tissue was exposed to the incubation waters. This was done to avoid direct contact with the sensitive tissue during experimental handling. Corals were then left to heal and acclimatize in the cultivation tanks, and algal overgrowth on the ceramic tiles and glue junction was removed regularly. For all collected organisms, special care was taken to exclude specimens infested by epibionts or endolithic boring organisms that could have possibly affected experimental results by release or uptake of organic matter.

Experimental setup. Each benthic species was incubated in an independent experiment using the method of Herndl \& Velimirov (1986) with some modifications as described by Naumann et al. (2010). A separate beaker was used for each specimen of each species. Briefly, 10 sulphuric acid-cleaned and seawater-rinsed glass beakers were filled with exactly $1000 \mathrm{ml}$ of sea water freshly collected from the lagoon; 5 beakers contained the selected specimens and the remaining 5 served as controls. During incubation of seagrasses, roots were tightly sealed off with a lightproof plastic cover to avoid rhizomal organic matter release. To assure in situ conditions, light intensity (lx) and water temperature $\left({ }^{\circ} \mathrm{C}\right)$ were recorded at the natural habitat of the collected specimens and during the incubation experiments every $5 \mathrm{~s}$ using light and temperature loggers (see above). Beaker incubations were carried out during daylight hours (10:00 to 16:00 h). Powder-free gloves were used during all experimental procedures to prevent contamination of the incubation water. After $6 \mathrm{~h}$ of incubation, the specimens were removed from the beakers using sterilised forceps, and the remaining incubation water was sampled and analysed as described below.

Quantification of released organic matter. Subsamples for dissolved organic carbon (DOC), particulate 
organic carbon (POC) and particulate organic nitrogen (PON) measurements were collected and processed as described by Naumann et al. (2010). For DOC analysis, aliquots of the incubation water $(5 \mathrm{ml})$ were filtered ( $0.2 \mu \mathrm{m}$ nominal particle retention via a polyethersulfone membrane) into pre-combusted amber glass vials and immediately frozen at $-20^{\circ} \mathrm{C}$ until analysis. DOC was measured by high-temperature catalytic oxidation (HTCO) using a Rosemount Dohrmann DC-190 TOC analyser. Potassium hydrogen phthalate was repeatedly measured as an elemental standard (standard deviation $<3 \%$ ).

Samples for POC and PON measurements (680 to $940 \mathrm{ml}$ ) were filtered onto precombusted GF/F filters (nominal particle retention of $0.7 \mu \mathrm{m}$ ). Filters were then dried for at least $48 \mathrm{~h}$ at $40^{\circ} \mathrm{C}$ and kept dry until further analysis. POC and PON contents on the filters were measured using an elemental analyser (THER$\mathrm{MO}^{\mathrm{TM}} 1112$ Flash EA). Peptone, atropine and cyclohexanone-2,4-dinitrophenylhydrazone were used as standards, and standard deviations of replicate measurements were $<3 \%$.

Nominal particle retentions of filters (DOM $<0.2 \mu \mathrm{m}$, POM $>0.7 \mu \mathrm{m}$ ) were chosen in order to achieve a distinct separation between the particulate and dissolved fraction. Even though previous studies have established DOC as organic compounds passing through a filter with a nominal pore size of about $0.45 \mu \mathrm{m}$, a smaller pore size was chosen for the present study in order to exclude picoplankton and bacteria from the DOM fraction (Dafner \& Wangersky 2002a,b, Mari et al. 2007, De Goeij et al. 2008). Some organic material released by the investigated organisms, especially colloidal-i.e. particles with a linear dimension (diameter) between 0.001 and $1 \mu \mathrm{m}$ (Hiemenz \& Rajagopalan 1997) - within the size range of 0.2 to $0.6 \mu \mathrm{m}$, may not have been covered by either DOM or POM measurements. Organic matter release rates presented here can, therefore, be considered as rather conservative data.

Quantification of microbial $\mathrm{O}_{2}$ consumption rates. To determine the influence of the released organic matter on microbial (including bacteria, archaea and microscopic planktonic eukaryotes as well as fungi and viruses) $\mathrm{O}_{2}$ consumption rates, a method described by Wild et al. (2004b) was used with some modifications. Sub-samples of each incubation water volume were taken at the end of each incubation experiment. The initial $\mathrm{O}_{2}$ concentration of each sub-sample was determined using the mean value of 5 replicate Optode (luminescent dissolved $\mathrm{O}_{2}$ sensor, HACH LANGE HQ10, precision $0.01 \mathrm{mg} \mathrm{l}^{-1}$, accuracy $\pm 0.05 \%$ ) measurements of the same water sample. Sub-samples were then kept at in situ temperature in airtight $60 \mathrm{ml}$ Winkler glass bottles in the dark. After 19 to $25 \mathrm{~h}, \mathrm{O}_{2}$ concentrations were measured again as described above. To calculate planktonic microbial $\mathrm{O}_{2}$ consumption rates, the end $\mathrm{O}_{2}$ concentration value was subtracted from start value and normalised by incubation duration.

Surface area determination. The surface area of all specimens was used as the reference parameter for quantification of organic matter release rates because of its functional importance as an ecological interface with the surrounding environment (Dahl 1973). Surface area was measured for each of the incubated seagrasses and macroalgae by spreading them 2-dimensionally on scaled paper and taking photographs (Sony Cybershot, resolution: 5.1 megapixels) directly from above. Digital image-processing software (ImageJ, V. $1.37 \mathrm{~m}$, National Institutes of Health) was then used to calculate surface areas. Coral surface areas were calculated according to the Advanced Geometry protocol, in combination with the respective approximation factors, introduced by Naumann et al. (2009).

Measurement of in situ $\mathrm{O}_{2}$ concentration. The effect of different benthic community compositions on in situ $\mathrm{O}_{2}$ availability in the overhead water column was assessed by deploying dissolved $\mathrm{O}_{2}$ loggers (Eureka Midge). On 6 different occasions between July 19 and August 2, 2 loggers were simultaneously deployed in locations almost exclusively ( $>90 \%$ ) dominated by one type of benthic organism or substrate (seagrass, algae, bare calcareous sand) within a radius of $1 \mathrm{~m}$ around the sensor. In situ $\mathrm{O}_{2}$ concentrations at coral-dominated locations could not be assessed in the study area, owing to their scattered abundance. Logger deployments took place in water depths of 3.0 to $3.5 \mathrm{~m}$. $\mathrm{O}_{2}$ concentrations and water temperatures were measured and logged every 5 min for at least $24 \mathrm{~h}$ during each deployment. Measurements conducted over a sand flat from July 29 to 30 were excluded from analysis because of presumed air entrapment under the membrane of the dissolved oxygen sensor, as $\mathrm{O}_{2}$ concentrations exceeded all other measured values with maximum $\mathrm{O}_{2}$ concentrations above $12 \mathrm{mg} \mathrm{l}^{-1}$.

Analysis of data and statistics. Net organic matter release (DOC, POM) by reef organisms was calculated by subtracting mean control values of the measured parameters from those of each treatment. Released organic matter was then normalised to surface area of the incubated organisms and incubation time. The organic carbon contribution of each primary producer to the lagoon organic matter pool was calculated from the product of the released total organic carbon (POC + DOC) and the benthic cover of the respective organism. For a comparable calculation of specimen-derived organic carbon turnover rates, the total organic carbon concentration $(\mu \mathrm{M})$ released by the organisms was then related to the elevated $\mathrm{O}_{2}$ consumption $(\mu \mathrm{M})$ in 
the respective treatment. Statistical evaluation of release rates by the respective organisms was carried out by analysis of variance (ANOVA), and homogeneity of variances was tested with a Levene test (Dytham 1999). Correlation of organic matter release and subsequent changes in the microbial $\mathrm{O}_{2}$ consumption rates were statistically analysed with a Model I regression to determine the coefficient of determination $\left(\mathrm{R}^{2}\right)$ and the probability $(\mathrm{p})$. All values are given as mean \pm SE.

\section{RESULTS}

\section{Environmental parameters}

Water temperature was $30.4 \pm 0.1^{\circ} \mathrm{C}$ during the study period with diurnal fluctuations of $2.0 \pm 0.1^{\circ} \mathrm{C}$. The maximum water temperature of $33.1^{\circ} \mathrm{C}$ was measured on July 17 and the minimum temperature of $28.4^{\circ} \mathrm{C}$ on July 22 following the tropical storm 'Dolly' that reached the coast on July 21. Effects of the tropical storm were also visible in light availability measurements (Fig. 2). Data obtained from in situ deployed light loggers revealed a mean average daytime (= incubation time, 10:00 to 16:00 h) PAR availability at $3 \mathrm{~m}$ water depth of $508 \pm 4 \mu \mathrm{mol}$ quanta $\mathrm{m}^{-2} \mathrm{~s}^{-1}$ during the study period. A maximum average daytime PAR availability of $625 \pm 17 \mu \mathrm{mol}$ quanta $\mathrm{m}^{-2} \mathrm{~s}^{-1}$ was recorded on July 28 and a minimum of $41 \pm 2 \mu \mathrm{mol}$ quanta $\mathrm{m}^{-2} \mathrm{~s}^{-1}$ on July 21 during the passage of the tropical storm (Fig. 2).

\section{Benthic community assessment}

The LPI transects revealed seagrasses as the most abundant benthic organisms in the study area (Table 1). The 2 dominant genera were Thalassia and Syringodium with $20.8 \pm 1.6 \%$ and $8.8 \pm 1.4 \%$ seafloor cover, respectively. Algae accounted for the second largest group with $26.9 \pm 3.5 \%$ seafloor cover. Dominant benthic algae were green algae of the genera

Table 1. Seafloor coverage (\%) by dominant benthic macroorganisms in the Puerto Morelos reef lagoon obtained from line point intercept (LPI) surveys. Values (mean \pm SE) are given along with water depth, distance from the coast and length of transect (50 $\mathrm{m}$ )

\begin{tabular}{|c|c|c|c|c|c|c|c|c|}
\hline \multirow{2}{*}{$\begin{array}{l}\text { Distance to } \\
\text { coast (m) }\end{array}$} & \multirow{2}{*}{$\begin{array}{l}\text { Water depth } \\
\qquad(\mathrm{m})\end{array}$} & \multirow{2}{*}{$\begin{array}{c}\text { Observed } \\
\text { distance }(\mathrm{m})\end{array}$} & \multirow{2}{*}{$\begin{array}{l}\text { Scleractinian } \\
\text { corals }\end{array}$} & \multirow[b]{2}{*}{ Seagrass } & \multicolumn{2}{|c|}{ Seafloor cover $(\%)$} & \multirow[b]{2}{*}{$\begin{array}{c}\text { Brown } \\
\text { algae }\end{array}$} & \multirow[b]{2}{*}{ Sand } \\
\hline & & & & & $\begin{array}{l}\text { Green } \\
\text { algae }\end{array}$ & $\begin{array}{c}\text { Red } \\
\text { algae }\end{array}$ & & \\
\hline 100 & $2.0-2.3$ & $2 \times 50$ & $1.0 \pm 1.0$ & $34.5 \pm 2.5$ & $15.5 \pm 2.5$ & $12.5 \pm 4.5$ & $13.0 \pm 11.0$ & $20.0 \pm 3.0$ \\
\hline 200 & $2.5-2.8$ & $4 \times 50$ & $4.3 \pm 1.5$ & $26.5 \pm 1.6$ & $29.5 \pm 0.9$ & $2.5 \pm 1.6$ & $0.8 \pm 0.8$ & $31.3 \pm 1.5$ \\
\hline 400 & 3.5 & $2 \times 50$ & $0.0 \pm 0.0$ & $24.5 \pm 0.5$ & $23.0 \pm 6.0$ & $4.0 \pm 0.0$ & $4.5 \pm 4.5$ & $43.5 \pm 2.5$ \\
\hline 800 & 2.5 & $2 \times 50$ & $1.0 \pm 0.5$ & $35.0 \pm 5.0$ & $14.5 \pm 1.5$ & $0.0 \pm 0.0$ & $0.0 \pm 0.0$ & $49.0 \pm 3.0$ \\
\hline 1000 & 2 & $2 \times 50$ & $1.5 \pm 0.8$ & $30.5 \pm 0.5$ & $8.0 \pm 1.0$ & $0.0 \pm 0.0$ & $1.0 \pm 1.0$ & $58.5 \pm 3.5$ \\
\hline Mean & & & $2.0 \pm 0.7$ & $29.6 \pm 1.5$ & $20.0 \pm 2.6$ & $3.6 \pm 1.5$ & $3.3 \pm 2.0$ & $38.9 \pm 4.0$ \\
\hline
\end{tabular}

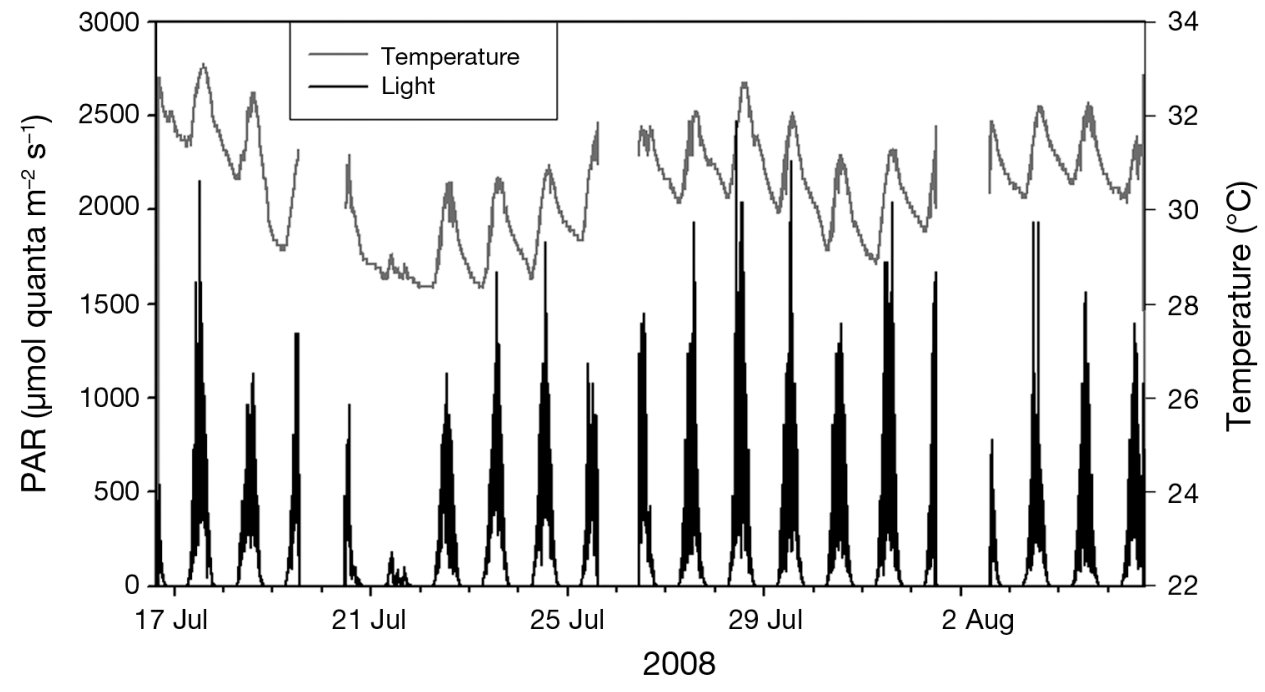

Fig. 2. In situ water temperatures $\left({ }^{\circ} \mathrm{C}\right)$ and photosynthetically active radiation (PAR, $\mu m o l$ quanta $\mathrm{m}^{-2} \mathrm{~s}^{-1}$ ) in the Puerto Morelos reef lagoon (water depth: $3 \mathrm{~m}$ ) during the entire study period from July 16 to August 6 
Table 2. Organic matter release rates and POC:PON ratios for dominant primary producers of the Puerto Morelos reef lagoon (mean \pm SE). Organic carbon contribution to the ecosystem was calculated from the product of organic matter release and benthic cover. Abbreviations: $\mathrm{DOC}=$ dissolved organic carbon, $\mathrm{POC}=$ particulate organic carbon, $\mathrm{PON}=$ particulate organic nitrogen, $\mathrm{OC}=$ organic carbon, $\mathrm{N}=$ number of replicate incubations, $\mathrm{bl}=$ bleached, $\mathrm{nd}=$ benthic cover not determined

\begin{tabular}{|c|c|c|c|c|c|c|c|}
\hline Organism & Genus & $\begin{array}{l}\text { DOC release } \\
\left(\mathrm{mg} \mathrm{m}^{-2} \mathrm{~h}^{-1}\right)\end{array}$ & $\begin{array}{l}\text { POC release } \\
\left(\mathrm{mg} \mathrm{m}^{-2} \mathrm{~h}^{-1}\right)\end{array}$ & $\begin{array}{l}\text { PON release } \\
\left(\mathrm{mg} \mathrm{m}^{-2} \mathrm{~h}^{-1}\right)\end{array}$ & POC:PON & $\begin{array}{c}\text { OC contribution } \\
(\%)\end{array}$ & $\mathrm{N}$ \\
\hline Seagrass & $\begin{array}{l}\text { Syringodium } \\
\text { Thalassia } \\
\text { Mean }\end{array}$ & $\begin{aligned} 29.9 & \pm 10.3 \\
2.2 & \pm 1.0 \\
\mathbf{1 5 . 8} & \pm \mathbf{6 . 0}\end{aligned}$ & $\begin{array}{l}5.6 \pm 4.0 \\
0.7 \pm 0.1 \\
\mathbf{3 . 1} \pm \mathbf{2 . 0}\end{array}$ & $\begin{array}{l}1.22 \pm 1.03 \\
0.08 \pm 0.01 \\
\mathbf{0 . 6 5} \pm \mathbf{0 . 5 2}\end{array}$ & $\begin{array}{r}7.9 \pm 0.9 \\
10.3 \pm 0.5 \\
\mathbf{9 . 1} \pm \mathbf{0 . 6}\end{array}$ & $\begin{array}{r}56 \\
8 \\
\text { Total } 64\end{array}$ & $\begin{array}{l}5 \\
5\end{array}$ \\
\hline Algae & $\begin{array}{l}\text { Halimeda } \\
\text { Avrainvillea } \\
\text { Rhipocephalus } \\
\text { Penicillus } \\
\text { Lobophora } \\
\text { Red algae } \\
\text { Mean }\end{array}$ & $\begin{aligned}-0.8 & \pm 3.4 \\
-6.0 & \pm 3.6 \\
12.1 & \pm 5.3 \\
3.0 & \pm 0.8 \\
10.2 & \pm 1.6 \\
12.4 & \pm 10.2 \\
\mathbf{1 . 9} & \pm \mathbf{2 . 0}\end{aligned}$ & $\begin{array}{r}1.9 \pm 0.5 \\
2.7 \pm 1.2 \\
10.4 \pm 2.7 \\
1.4 \pm 0.2 \\
1.4 \pm 0.6 \\
7.7 \pm 0.4 \\
\mathbf{3 . 9} \pm \mathbf{0 . 7}\end{array}$ & $\begin{array}{l}0.18 \pm 0.07 \\
0.42 \pm 0.23 \\
0.64 \pm 0.16 \\
0.22 \pm 0.15 \\
0.09 \pm 0.05 \\
0.56 \pm 0.04 \\
\mathbf{0 . 3 4} \pm \mathbf{0 . 0 7}\end{array}$ & $\begin{array}{l}16.2 \pm 0.9 \\
13.4 \pm 1.0 \\
16.5 \pm 1.4 \\
15.3 \pm 0.9 \\
16.5 \pm 2.2 \\
14.7 \pm 0.3 \\
\mathbf{1 5 . 3} \pm \mathbf{0 . 5}\end{array}$ & $\begin{array}{r}3 \\
-4 \\
4 \\
1 \\
11 \\
23 \\
\text { Total } 38\end{array}$ & $\begin{array}{r}10 \\
10 \\
5 \\
5 \\
5 \\
5\end{array}$ \\
\hline $\begin{array}{l}\text { Scleractinian } \\
\text { coral }\end{array}$ & $\begin{array}{l}\text { Manicina } \\
\text { Porites } \\
\text { Porites bl } \\
\text { Mean }\end{array}$ & $\begin{aligned}-156.5 & \pm 43.0 \\
38.1 & \pm 19.9 \\
49.4 & \pm 9.9 \\
\mathbf{- 2 8 . 6} & \pm \mathbf{3 4 . 2}\end{aligned}$ & $\begin{array}{c}17.5 \pm 12.1 \\
4.5 \pm 1.6 \\
2.5 \pm 0.8 \\
\mathbf{8 . 2} \pm \mathbf{4 . 2}\end{array}$ & $\begin{array}{l}2.11 \pm 1.01 \\
0.61 \pm 0.20 \\
0.44 \pm 0.14 \\
\mathbf{1 . 0 5} \pm \mathbf{0 . 3 8}\end{array}$ & $\begin{array}{r}11.1 \pm 0.6 \\
9.3 \pm 1.5 \\
6.2 \pm 1.2 \\
\mathbf{1 0 . 7} \pm \mathbf{0 . 3}\end{array}$ & $\begin{array}{r}-14 \\
12 \\
\text { nd } \\
\text { Total }-2\end{array}$ & $\begin{array}{l}5 \\
5 \\
5\end{array}$ \\
\hline
\end{tabular}

Halimeda (9.6 $\pm 1.6 \%)$, Avrainvillea $(7.9 \pm 1.5 \%)$, Rhipocephalus $(1.3 \pm 0.5 \%)$ and Penicillus $(1.0 \pm 0.5 \%)$, brown algae, mainly of the genus Lobophora $(3.3 \pm$ $2.0 \%)$ and several unidentified red algae $(3.6 \pm 1.5 \%)$. Scleractinian corals of the genera Porites $(1.4 \pm 0.6 \%)$ and Manicina $(0.6 \pm 0.3)$ represented the third largest group of benthic primary producers. The largest proportion of seafloor in the Puerto Morelos reef lagoon was covered by bare calcareous sand (38.9 $\pm 4.0 \%)$.

\section{Organic matter release quantification}

All investigated benthic organisms showed a significant release of POC (1-way ANOVA, p < 0.001) and PON (1-way ANOVA, p < 0.001) over the incubation period. Contrary to POC and PON, DOC release rates varied significantly between the different groups of organisms (1-way ANOVA, p < 0.001). Highest release rates by all tested organism groups were found for seagrass $\left(15.8 \pm 6.0 \mathrm{mg} \mathrm{m}^{-2} \mathrm{~h}^{-1}\right)$ and benthic algae $(1.9 \pm$ $\left.2.0 \mathrm{mg} \mathrm{m}^{-2} \mathrm{~h}^{-1}\right)$. Corals displayed a mean net DOC uptake of $28.6 \pm 34.2 \mathrm{mg} \mathrm{m}^{-2} \mathrm{~h}^{-1}$ (Table 2).

Seagrass. All seagrass incubations showed significantly elevated concentrations of both, POC (1-way ANOVA, p < 0.001) and DOC (1-way ANOVA, p < 0.001), when compared to the seawater controls. Seagrass exuded the highest quantity of total organic carbon per surface area of all tested benthic organisms in the Puerto Morelos lagoon. However, release rates of Syringodium exceeded those of Thalassia by more than 1 order of magnitude. A high DOC:POC ratio of $10.3 \pm 4.4$ revealed that most of the organic matter was released in dissolved form. The C:N ratio of the re- leased particulate organic matter (POM) of $9.1 \pm 0.6$ did not significantly differ from those found for POM suspended in the seawater controls.

Algae. POC (1-way ANOVA, p < 0.001) and PON (1way ANOVA, $p<0.001)$ concentrations were significantly elevated in all algae incubations when compared to the seawater controls. DOC release rates were more heterogeneous and varied from $12.4 \pm$ $10.2 \mathrm{mg} \mathrm{m}^{-2} \mathrm{~h}^{-1}$ for red algae to a net DOC uptake of $6.0 \pm 3.6 \mathrm{mg} \mathrm{m}^{-2} \mathrm{~h}^{-1}$ for the green algae Avrainvillea when compared to the respective seawater controls. This was also reflected in low, but highly variable DOC:POC ratios (average $0.53 \pm 3.40$ ). The $\mathrm{C}: \mathrm{N}$ ratio of algae-released POM (15.3 \pm 0.5$)$ was higher than those of the investigated seagrasses, corals and seawater controls, but not at a statistically significant level.

Corals. Organic matter release rates by scleractinian corals were highly species-specific. POC (3.5 $\pm 0.9 \mathrm{mg}$ $\left.\mathrm{m}^{-2} \mathrm{~h}^{-1}\right)$ and PON $\left(0.53 \pm 0.12 \mathrm{mg} \mathrm{m}^{-2} \mathrm{~h}^{-1}\right)$ release rates of both Porites samples, bleached and unbleached, were comparable to those of seagrasses and benthic algae. Release rates of POC $\left(17.5 \pm 12.1 \mathrm{mg} \mathrm{m}^{-2} \mathrm{~h}^{-1}\right)$ and PON $\left(2.11 \pm 1.01 \mathrm{mg} \mathrm{m}^{-2} \mathrm{~h}^{-1}\right)$ by Manicina significantly exceeded those of all other tested benthic organisms (1-way ANOVA, p < 0.001). In contrast, Porites displayed the significantly highest DOC release rates of all organisms during the incubation period (1-way ANOVA, p =0.011), as opposed to highest net DOC uptake rates by Manicina (1-way ANOVA, $\mathrm{p}<0.001)$. The particulate organic $\mathrm{C}: \mathrm{N}$ ratio of all investigated corals $(10.7 \pm 0.3)$ was in the same range as those measured for seagrasses and algae, and showed no significant difference to the respective seawater controls. 
Taking into account the overall abundance of the investigated organism groups in the study area and the average combined total carbon release rates, seagrasses were the main benthic contributors to the organic carbon pool (64\%) in this lagoon ecosystem, followed by algae (38\%); scleractinian corals (both species pooled) were found to be net consumers $(-2 \%)$ of organic carbon (Table 2).

\section{Influence of released organic matter on microbial $\mathrm{O}_{2}$ consumption}

Microbial $\mathrm{O}_{2}$ consumption in the incubation water of all different investigated specimens was significantly elevated when compared to the respective seawater controls (1-way ANOVA, p < 0.001). However, benthic algae incubations led to a significantly higher stimulation (1-way ANOVA, $\mathrm{p}<0.001$ ) of microbial $\mathrm{O}_{2}$ consumption in the incubation water and higher total organic carbon turnover rates (1-way ANOVA, p = 0.001) when compared to seagrass and coral incubations. Organic carbon quantities released by investigated benthic primary producers displayed significant,

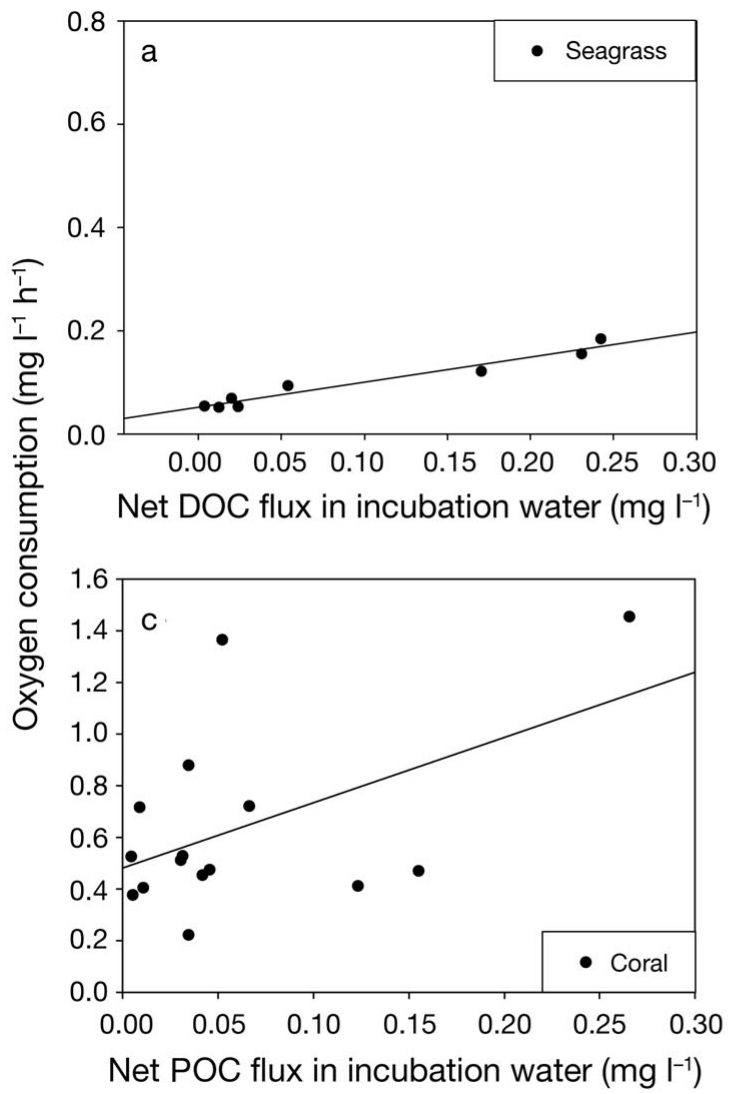

but group-specific correlations with subsequent changes in microbial $\mathrm{O}_{2}$ consumption rates (Fig. 3) as summarised below.

Seagrasses and algae. A direct correlation was found for both seagrasses $\left(\mathrm{R}^{2}=0.950\right.$; ANOVA $\mathrm{p}<$ 0.001) (Fig. 3a) and algae $\left(\mathrm{R}^{2}=0.647\right.$; ANOVA $\mathrm{p}<$ 0.001) (Fig. 3b) between released DOC and stimulation of microbial $\mathrm{O}_{2}$ consumption rates. DOC turnover rates were $2.8 \pm 1.0$ and $6.9 \pm 1.0 \% \mathrm{C} \mathrm{h}^{-1}$ for seagrasses and algae, respectively. No correlation between the quantity of POC released by seagrasses and algae and the subsequently increased microbial $\mathrm{O}_{2}$ consumption rates could be detected.

Corals. In contrast to seagrasses and algae, the quantity of POC released by corals showed a significant positive correlation to stimulation of microbial $\mathrm{O}_{2}$ consumption rates $\left(\mathrm{R}^{2}=0.561\right.$; ANOVA $\left.\mathrm{p}=0.029\right)$ (Fig. 3c) with total organic carbon turnover rates of 3.0 $\pm 1.2 \% \mathrm{C} \mathrm{h}^{-1}$. While increased microbial $\mathrm{O}_{2}$ consumption rates were found in all coral incubations compared to the seawater controls, the quantity of DOC in the respective coral treatments was negatively correlated to the stimulation of microbial $\mathrm{O}_{2}$ consumption $\left(\mathrm{R}^{2}=\right.$ 0.811; ANOVA p < 0.001) (Fig. 3d).
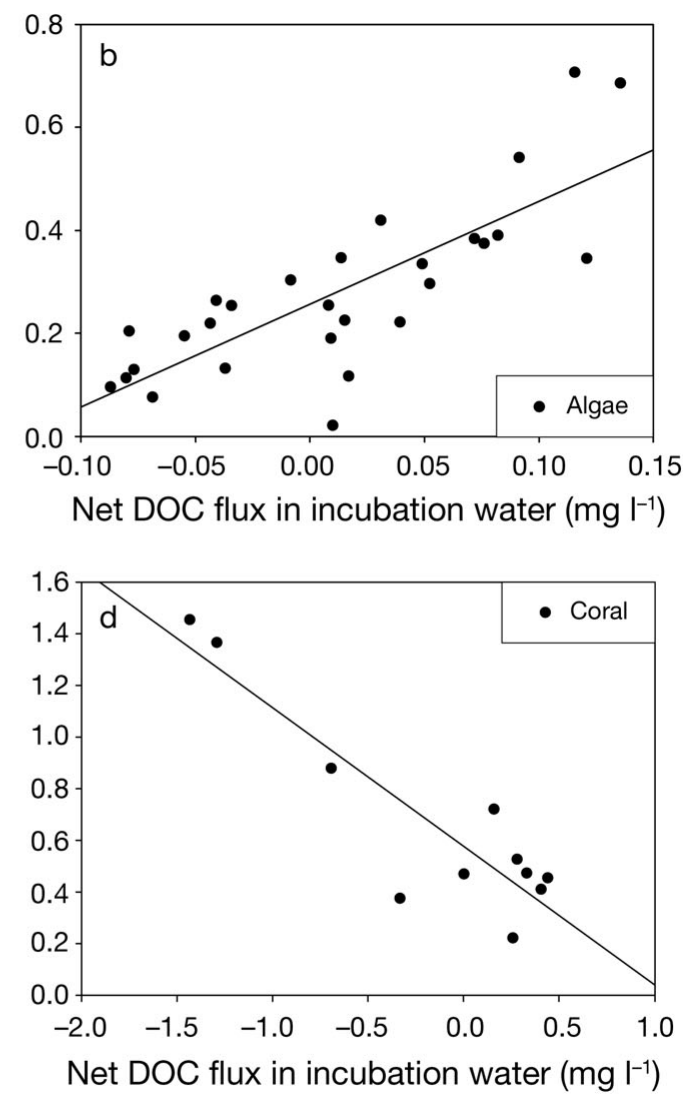

Fig. 3. Correlation of organic carbon released by the investigated organisms and subsequent changes in microbial $\mathrm{O}_{2}$ consumption rates in the incubation water. $\mathrm{O}_{2}$ consumption rates are plotted against net fluxes of dissolved organic carbon (DOC) for (a) seagrasses and (b) algae, (c) particulate organic carbon (POC) for corals and (d) DOC for corals 


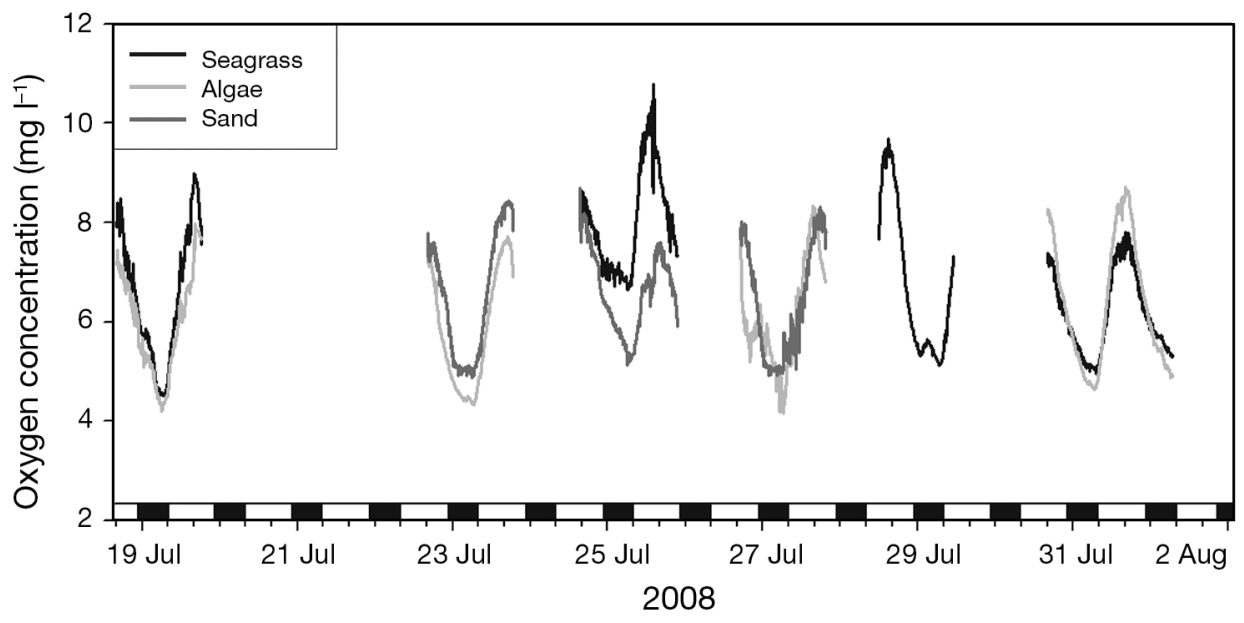

Fig. 4. $\mathrm{O}_{2}$ concentrations $\left(\mathrm{mg} \mathrm{l}^{-1}\right.$ ) measured using in situ dissolved $\mathrm{O}_{2}$ loggers in the Puerto Morelos reef lagoon at seagrass- and algae-dominated sites as well as above sand flats. Day (white) and night (black) phases are indicated by the horizontal bar

\section{In situ $\mathrm{O}_{2}$ measurements}

All logger measurements of diurnal in situ $\mathrm{O}_{2}$ concentration are plotted in Fig. 4. Highest daily $\mathrm{O}_{2}$ concentrations, around 15:50 h, were measured directly above seagrass-dominated areas $\left(9.1 \pm 0.7 \mathrm{mg} \mathrm{l}^{-1}\right)$, followed by sand flats $\left(8.3 \pm 0.1 \mathrm{mg} \mathrm{l}^{-1}\right)$ and algae-dominated areas $\left(7.9 \pm 0.5 \mathrm{mg} \mathrm{l}^{-1}\right)$. Lowest $\mathrm{O}_{2}$ concentrations, measured in the early morning (around 06:30 h), were found for algae-dominated areas $(4.4 \pm 0.1 \mathrm{mg}$ $\left.\mathrm{l}^{-1}\right)$, followed by sand flats $\left(5.0 \pm 0.1 \mathrm{mg} \mathrm{l}^{-1}\right)$ and seagrass-dominated areas $\left(5.2 \pm 0.4 \mathrm{mg} \mathrm{l}^{-1}\right)$. Average $\mathrm{O}_{2}$ concentrations in algae-dominated compared to sand flat- and seagrass-dominated locations were significantly lower (repeated-measure ANOVA, p < 0.001) and displayed the highest fluctuations.

\section{DISCUSSION}

\section{Benthic coverage and organic matter release by different lagoon organisms}

\section{Seagrasses and algae}

The results of the benthic community assessment in the Puerto Morelos reef lagoon identified seagrasses as the dominant benthic macroorganisms, followed by algae and corals. This is in agreement with benthic community structure surveys conducted 10 yr earlier by Ruíz-Rentería et al. (1998). In addition to their predominant abundance, seagrasses also displayed the highest organic matter release rates measured for benthic organisms in the present study, mainly owing to the release of DOC. This supports their role as dominant primary producers (Ziegler \& Benner 1999) and major contributors to the organic matter pool in shallow reef lagoon ecosystems (Ziegler \& Benner 2000).

Even though the relatively tall seagrasses dominated the ecosystem visually, the mean contribution of the shorter macroalgae to benthic community structure was lower only on a statistically insignificant level. Green algae, namely Halimeda and Avrainvillea, accounted for the majority of benthic algae cover in the study area. Due to their lower or negative net DOC release rates, however, the overall contribution of green algae to the organic carbon pool was not significant. This is in contrast to preliminary studies from the northern Red Sea (Wild et al. 2009, Haas et al. 2010), which showed a notable contribution of coral reef-associated green macroalgae to the DOC pool. A possible explanation for these differences is the sensitivity of green macroalgae towards excessive irradiance (Hanelt et al. 1993, Larkum \& Wood 1993). A connection between average daytime PAR levels above 300 to $500 \mu \mathrm{mol}$ quanta $\mathrm{m}^{-2} \mathrm{~s}^{-1}$ and reduced DOC release rates, potentially owing to photoinhibition, has already been suggested by a previous study (Haas et al. 2010). Furthermore, Hanelt (1992) showed that different algae species and seagrasses can display significant variations in susceptibility to high irradiance levels. Species-specific investigations of excessive irradiance and photoinhibition have shown a high irradiance compatibility of seagrasses and the brown algae Lobophora, whereas the onset of photoinhibition for green algae (e.g. Ulva, Halimeda) occurred at significantly lower irradiance levels (Hanelt 1992, Franklin et al. 1996, Enriquez et al. 2002). This is in line with the present study, as particularly red algae and brown algae of the genus Lobophora showed high organic matter release rates and were, next to seagrasses, substantial contributors to the organic carbon pool in the studied reef lagoon. 
Corals

Overall, corals showed the highest average release rates of POC and PON accompanied by the highest average net DOC uptake, resulting in a negative total organic carbon balance. However, pronounced speciesspecific differences were visible. Scleractinian corals are commonly known to release organic compounds in particulate and dissolved forms into the surrounding seawater (Crossland 1987, Ferrier-Pages et al. 1998), thereby contributing to reef trophodynamics (Benson \& Muscatine 1974, Wild et al. 2004a,b). However, they may also function as suspension feeders (Di Salvo 1971, Sorokin 1973, Porter 1974) and saprotrophs (Stephens 1962), via uptake of organic substances from seawater. Therefore, varying feeding modes may explain the pronounced differences between the incubated coral specimens in the present study.

POC and PON release of both Porites specimens, bleached and unbleached, was in the same range as previously described for various scleractinian corals in the northern Red Sea (Naumann et al. 2010). Porites exudates also displayed high DOC:POC ratios, similar to those of the other major carbon contributors (seagrasses, brown and red algae). In contrast to their relatively small contribution to the overall benthic cover, Porites contribute notably to the total organic carbon pool in the investigated lagoon ecosystem, owing to their comparably high organic matter release rates.

Although Manicina displayed the highest POC and PON release rates of all incubated organisms, a significant uptake of total organic carbon was found, as DOC uptake rates exceeded POC release rates by about 1 order of magnitude. A possible explanation for the striking differences in coral organic matter release rates can be found in the simultaneously measured background parameters. Incubation experiments conducted with Manicina coincided with the highest mean PAR availability ( $23 \%$ above average) and temperature $\left(1.9^{\circ} \mathrm{C}\right.$ above average) of all incubation days. High temperature (Glynn 1993, Brown 1997), excessive light availability (Lesser \& Shick 1989) and, foremost, the combination of both (Hoegh-Guldberg \& Smith 1989, Lesser et al. 1990, Glynn et al. 1992) can result in the onset of bleaching as a direct response of corals to these environmental stressors. Thereby, the release of zooxanthellae can be responsible for increased POM release rates by corals. Additionally, corals have been shown to increase the release rate of POM via mucoid exudates, as a general stress response (Niggl et al. 2009). Studies conducted on organic matter release by corals during the onset of bleaching (Niggl et al. 2009) showed increased release of mucoid exudates, presumably to decrease their vulnerability to pathogens (Brown \& Bythell 2005).
During the onset of bleaching, a decrease in photosynthetic activity and efficiency (Iglesias-Prieto et al. 1992, Fitt \& Warner 1995, Warner et al. 1996) leads to a reduced net organic carbon production (Fujimura et al. 2001). The insufficient energy supply arising as a consequence of this may then be satisfied by the uptake of DOC.

The equal quantities and qualities of exudates from bleached and healthy Porites specimens (POM) may be explained by the hypothesis that mucus-POM release by corals is only stimulated during the early phase of bleaching, but drops down to lower levels during longer bleaching periods.

\section{Effects of released organic matter on microbial activity}

Organic carbon released by the different benthic primary producers was group-specifically correlated to increases in planktonic microbial $\mathrm{O}_{2}$ consumption rates. This indicates differences in the chemical composition of the released organic compounds with ensuing effects on microbial degradability as discussed below.

\section{Seagrass and algae}

Seagrass and algae incubation samples showed a significant positive correlation between DOC release and elevated microbial $\mathrm{O}_{2}$ consumption rates (Fig. 3a,b). This is in line with studies of Ziegler \& Benner (1999), who demonstrated a positive correlation between $\mathrm{O}_{2}$ consumption measured in the water column and fluctuations in DOC release by seagrasses and algae in situ. Both groups of organisms have already been described as supporting their microbial environment by the release of organic carbon (Benner et al. 1986, Findlay et al. 1986). However, the present study indicates that algae-derived organic carbon provides a more attractive substratum for the ambient microbial community than organic carbon released by seagrasses. In general, algae incubations did not exhibit the highest release rates for any of the measured parameters (DOC, POC, PON), but resulted in the significantly highest microbial $\mathrm{O}_{2}$ consumption rates, thus leading to the highest carbon turnover rates. The quantity of POM (POC and PON) released by both seagrasses and algae showed no direct effect on microbial $\mathrm{O}_{2}$ consumption, indicating a better microbial degradability of the dissolved compared to the particulate fraction of the released organic material. This is also in agreement with studies of Ziegler \& Benner (2000), who suggested that the benthic release of DOC is 
primarily responsible for increases in bacterial production and that bacterioplankton production in seagrass ecosystems is not limited by bioavailable nitrogen.

\section{Corals}

In contrast to seagrass and algae treatments, increased POC concentrations in coral incubation waters were positively correlated with subsequent microbial $\mathrm{O}_{2}$ consumption. Wild et al. (2004b) have already summarised that the gel-like coral mucus carbohydrate complex (Coffroth 1990) contains energy-rich lipid compounds and proteins or peptides (Krupp 1985, Vacelet \& Thomassin 1991), thereby providing an attractive energy source for the whole ecosystem. However, turnover rates of organic carbon released by corals were in the same range as those of seagrass exudates, but significantly lower than those measured for exudates of benthic algae.

Even though microbial $\mathrm{O}_{2}$ consumption rates were increased in all coral incubation samples, the amount of DOC in these samples was negatively correlated to elevations of microbial $\mathrm{O}_{2}$ consumption. While the particulate fraction notably enhanced microbial $\mathrm{O}_{2}$ consumption rates in coral incubation waters, this could indicate suppressive effects of the dissolved fraction on microbial activity (Fig. 3c,d). Previous studies of Ritchie \& Smith (2004) have already shown that coral mucus may act as a medium for secreted allelochemicals with antimicrobial properties (Brown \& Bythell 2005). The findings of the present study therefore suggest that antimicrobial compounds potentially associated with coral mucus (Koh 1997, Geffen \& Rosenberg 2005, Ritchie 2006) may be mainly contained in the dissolved fraction of coral-derived organic matter.

\section{In situ $\mathrm{O}_{2}$ availability}

The diurnal $\mathrm{O}_{2}$ data obtained from locations dominated by a specific type of benthic cover revealed significantly lower $\mathrm{O}_{2}$ water concentrations at algaedominated sites compared to adjacent sand flats and seagrass-dominated sites. Influences of topography and differences in water currents are unlikely, owing to the regularity of the lagoon ground and homogeneous water currents within the lagoon (Merino-Ibarra \& Otero-Dávalos 1991, Coronado et al. 2007). However, the comparatively short water residence time in the study area ( $3 \mathrm{~h}$ ) helps to establish a rapidly degradable DOC pool (Mari et al. 2007). Overall, the higher $\mathrm{O}_{2}$ concentration in seagrass-dominated areas could be attributed to a higher abundance and photosyn- thetic performance of seagrasses compared to algae in the given environmental conditions (Hanelt 1992, Franklin et al. 1996). However, the occurrence of highest fluctuations between minimum and maximum $\mathrm{O}_{2}$ concentrations at algae locations and the more than 2 times higher turnover rates of organic carbon released by benthic algae compared to seagrasses indicate elevated microbial activity as the prime reason for reduced $\mathrm{O}_{2}$ concentrations in algae-dominated areas. These assumptions are supported by previous studies, which have shown that lagoons dominated by macroalgae often exhibit large diurnal changes in $\mathrm{O}_{2}$ concentrations (Sand-Jensen \& Borum 1991, Viaroli et al. 1995). The rapid changes in benthic metabolism may arise from a faster degradation of algae-derived organic matter, because of its high nutrient content, low content of structural components (e.g. lignin, cellulose, xylan) and its high C:N ratio (Enriquez et al. 1993). This confirms assumptions about the in situ relevance of group-specific effects of released organic matter on their adjacent environment (Kline et al. 2006, Wild et al. 2009), whereby particularly algaederived organic matter may lead to reductions in $\mathrm{O}_{2}$ availability. Niggl et al. (2010) have shown that the percentage benthic algae cover is directly positively related to nocturnal minimum oxygen concentrations and variations of diurnal oxygen concentrations. Previous studies (Nilsson \& Östlund-Nilsson 2004) have revealed that hypoxia occurs commonly in coral reef ecosystems. Further, reduced oxygen concentrations, owing to the presence of macroalgae (Barott et al. 2009), may then lead to deleterious consequences (hypoxia, anoxia) for other organisms in the ecosystem (Smith et al. 2006).

\section{Ecological implications}

Although the highest contribution to the organic matter pool was provided by seagrasses, algae had the strongest effect on planktonic microbial $\mathrm{O}_{2}$ consumption rates, which could also be verified for in situ conditions. Not only the turnover rate, but also the location of organic matter degradation may have implications for $\mathrm{O}_{2}$ concentrations in the water column. Coralderived organic matter is mainly (>90\%) degraded in the sediment (Wild et al. 2004a) or by invertebrates in coral cavities (De Goeij \& Van Duyl 2007, De Goeij et al. 2008) and not in the water column. The primary location for seagrass-derived organic matter is also the sediment rather than the water column (Canuel \& Martens 1996, Duarte \& Cebrián 1996, Kaldy et al. 2006), as a main part of organic carbon is released through roots and rhizomes (Hansen et al. 2000), and it is generally more refractory compared to algae exu- 
dates. Algae exudates, on the contrary, are likely primarily degraded in the water column. The high planktonic turnover rates found in the incubation experiments of the present study are supported by the investigations of Duarte \& Cebrián (1996), who showed that the fraction of organic matter reaching the sediments was 4 -fold higher for seagrass than for benthic macroalgae exudates.

This further strengthens the role of benthic algae exudates as agent, rapidly stimulating planktonic microbial $\mathrm{O}_{2}$ consumption (Wild et al. 2009). The previous studies of Rochelle-Newall et al. (2008) suggest that planktonic primary production is usually sufficient to support heterotrophic bacterial demands in coastal ecosystems. The findings therefore support the hypothesis that a surplus of rapidly degradable algaederived organic matter may have deleterious consequences on organisms in the direct vicinity owing to microbial-induced $\mathrm{O}_{2}$ depletion (Kline et al. 2006, Smith et al. 2006, Dinsdale et al. 2008).

Overall, the present study shows that all investigated groups of organisms displayed the ability to alter the organic matter pool of the lagoon ecosystem. Organic matter release rates of Caribbean lagoon-associated primary producers were therefore in the same range as those found for coral reef-associated primary producers, scleractinian corals (Naumann et al. 2010) and benthic macroalgae and turf algae (Haas et al. 2010) in the northern Red Sea. It simultaneously supports the assumption of organism-specific differences in the ecological properties of the released organic matter (Wild et al. 2009) because of variations in the rate and location of its (primarily microbial) utilisation.

Acknowledgements. The authors thank the staff of the Instituto de Ciencias del Mar y Limnologia (UNAM), in particular F. Colombo and C. Morera Román, for welcoming us at the station and their logistical support. W. Niggl, C. Williamson (CORE, Munich) and Dr. U. Struck (Museum für Naturkunde, Humboldt-Universität zu Berlin) helped in sample analysis. We also acknowledge improvement to the manuscript by the responsible editor Dr. Peter Edmunds and 3 anonymous reviewers. This work was funded by German Research Foundation (DFG) grant Wi 2677/2-1 to C.W. and Bleaching Work Group funding within the CRTR project.

\section{LITERATURE CITED}

Azam F, Smith DC, Steward GF, Hagström Å (1994) Bacteriaorganic matter coupling and its significance for oceanic carbon cycling. Microb Ecol 28:167-179

Barott K, Smith J, Dinsdale E, Hatay M, Sandin S, Rohwer F (2009) Hyperspectral and physiological analyses of coralalgal interactions. PLoS ONE 4:e8043, doi: 10.1371/journal. pone.0008043

Benner R, Peele E, Hodson RE (1986) Microbial utilization of dissolved organic matter from leaves of the red mangrove,
Rhizophora mangle, in the Fresh Creek estuary, Bahamas. Estuar Coast Shelf Sci 23:607-619

Benson A, Muscatine L (1974) Wax in coral mucus-energy transfer from corals to reef fishes. Limnol Oceanogr 19: 810-814

Biber PD, Harwell MA, Cropper Jr. WP (2004) Modeling the dynamics of three functional groups of macroalgae in tropical seagrass habitats. Ecol Model 175:25-54

> Brown BE (1997) Coral bleaching: causes and consequences. Coral Reefs 16:S129-S138

> Brown BE, Bythell JC (2005) Perspectives on mucus secretion in reef corals. Mar Ecol Prog Ser 296:291-309

> Brylinsky M (1977) Release of dissolved organic matter by some marine macrophytes. Mar Biol 39:213-220

Canuel EA, Martens CS (1996) Reactivity of recently deposited organic matter: degradation of lipid compounds near the sediment-water interface. Geochim Cosmochim Acta 60:1793-1806

Castel J, Caumette P, Herbert R (1996) Eutrophication gradients in coastal lagoons as exemplified by the Bassin d'Archon and Etang du Provost. Hydrobiologia 329:9-28

Coffroth MA (1990) Mucous sheet formation on poritid corals - an evaluation of coral mucus as a nutrient source on reefs. Mar Biol 105:39-49

Collado-Vides L, Ortegon-Aznar I, Granados AS, Comba-Barrera L, Gonzalez-Gonzalez J (1998) Macroalgae of Puerto Morelos reef system, Mexican Caribbean. Hidrobiologica 8:133-143

Coronado C, Candela J, Iglesias-Prieto R, Sheinbaum J, Lopez M, Ocampo-Torres FJ (2007) On the circulation in the Puerto Morelos fringing reef lagoon. Coral Reefs 26: 149-163

Costanza R, d'Arge R, de Groot R, Farber S and others (1997) The value of the world's ecosystem services and natural capital. Nature 387:253-260

Crossland CJ (1987) In situ release of mucus and DOC-lipid from the corals Acropora variabilis and Stylophora pistillata in different light regimes. Coral Reefs 6:35-42

> Dafner EV, Wangersky PJ (2002a) A brief overview of modern directions in marine DOC studies Part I-Methodological aspects. J Environ Monit 4:48-54

Dafner EV, Wangersky PJ (2002b) A brief overview of modern directions in marine DOC studies Part II-Recent progress in marine DOC studies. J Environ Monit 4:55-69

> Dahl AL (1973) Surface area in ecological analysis: quantification of benthic coral-reef algae. Mar Biol 23:239-249

De Goeij JM, Van Duyl FC (2007) Coral cavities are sinks of dissolved organic matter (DOC). Limnol Oceanogr 52: 2608-2617

> De Goeij JM, Van den Berg H, Van Oostveen MM, Epping EHG, Van Duyl FC (2008) Major bulk dissolved organic carbon (DOC) removal by encrusting coral reef cavity sponges. Mar Ecol Prog Ser 357:139-151

Di Salvo L (1971) Ingestion and assimilation of bacteria by two scleractinian coral species. In: Lenhoff HM, Muscatine L, Davis LV (eds) Experimental coelenterate biology. University of Hawaii Press, Honolulu, p 129-136

Dinsdale EA, Pantos O, Smriga S, Edwards RA and others (2008) Microbial ecology of four coral atolls in the Northern Line Islands. PLoS ONE 3:e1584, doi: 10.1371/journal. pone.0001584

Duarte CM, Cebrián J (1996) The fate of marine autotrophic production. Limnol Oceanogr 41:1758-1766

Dytham C (1999) Choosing and using statistics - a biologist's guide, 2nd ed. Blackwell Publishing, Oxford

Enriquez S, Duarte CM, Sand-Jensen K (1993) Patterns in decomposition rates among photosynthetic organisms: the 
importance of detritus C:N:P content. Oecologia 94: 457-471

Enriquez S, Merino M, Iglesias-Prieto R (2002) Variations in the photosynthetic performance along the leaves of the tropical seagrass Thalassia testudinum. Mar Biol 140: 891-900

$>$ Eyre BD, Ferguson AJP (2002) Comparison of carbon production and decomposition, benthic nutrient fluxes and denitrification in seagrass, phytoplankton, benthic microalgaeand macroalgae-dominated warm-temperate Australian lagoons. Mar Ecol Prog Ser 229:43-59

> Ferrier-Pagès C, Gattuso JP, Cauwet G, Jaubert J, Allemand D (1998) Release of dissolved organic carbon and nitrogen by the zooxanthellate coral Galaxea fascicularis. Mar Ecol Prog Ser 172:265-274

> Ferrier-Pagès C, Leclercq N, Jaubert J, Pelegrí SP (2000) Enhancement of pico- and nanoplankton growth by coral exudates. Aquat Microb Ecol 21:203-209

Findlay S, Carlough L, Crocker MT, Gill HK, Meyer JL, Smith PJ (1986) Bacterial growth on macrophyte leachate and fate of bacterial production. Limnol Oceanogr 31: 1335-1341

> Fitt WK, Warner ME (1995) Bleaching patterns of four species of Caribbean reef corals. Biol Bull 189:298-307

Fonseca MS, Kenworthy WJ, Whitfield PE (2000) Temporal dynamics of seagrass landscapes: a preliminary comparison of chronic and extreme disturbance events. Biol Mar Mediterr 7:373-376

- Franklin LA, Seaton GGR, Lovelock CE, Larkum AWD (1996) Photoinhibition of photosynthesis on a coral reef. Plant Cell Environ 19:825-836

Fujimura H, Oomori T, Maehira T, Miyahira K (2001) Change of coral carbon metabolism influenced by coral bleaching. Galaxea 3:41-50

Geffen Y, Rosenberg E (2005) Stress-induced rapid release of antibacterials by scleractinian corals. Mar Biol 146: 931-935

Glynn PW (1993) Coral bleaching: ecological perspectives. Coral Reefs 12:1-17

Glynn PW, Imai R, Sakai K, Nakano Y, Yamazato K (1992) Experimental responses of Okinawan (Ryukyu Islands, Japan) reef corals to high sea temperature and UV radiation. Proc 7th Int Coral Reef Symp, Guam 1:27-37

Haas AF, Naumann MS, Struck U, Mayr C, el-Zibdah M, Wild C (2010) Organic matter release by coral reef associated benthic algae in the northern Red Sea. J Exp Mar Biol Ecol 389:53-60

> Hanelt D (1992) Photoinhibition of photosynthesis in marine macrophytes of the South China Sea. Mar Ecol Prog Ser 82:199-206

Hanelt D, Huppertz K, Nultsch W (1993) Daily course of photosynthesis and photoinhibition in marine macroalgae investigated in the laboratory and field. Mar Ecol Prog Ser 97:31-37

> Hansen JW, Udy JW, Perry CJ, Dennison WC, Lomstein BAa (2000) Effect of the seagrass Zostera Capricorni on sediment microbial processes. Mar Ecol Prog Ser 199:83-96

Hemminga MA, Duarte CM (2000) Seagrass ecology. Cambridge University Press, Cambridge

Herndl GJ, Velimirov B (1986) Microheterotrophic utilization of mucus released by the Mediterranean coral Cladocora cespitosa. Mar Biol 90:363-369

Hiemenz PC, Rajagopalan R (1997) Principles of colloid and surface chemistry. Marcel Dekker, New York, NY

Hodgson G, Kiene W, Mihaly J, Liebeler J, Shuman C, Maun L (2004) Reef check instruction manual: a guide to reef check coral reef monitoring. Reef Check, Los Angeles, CA
Hoegh-Guldberg O, Smith GJ (1989) The effect of sudden changes in temperature, light and salinity on the population density and export of zooxanthellae from the reef corals Stylophora pistillata Esper and Seriatopora hystrix Dana. J Exp Mar Biol Ecol 129:279-303

> Huettel M, Wild C, Gonelli S (2006) Mucus trap in coral reefs: formation and temporal evolution of particle aggregates caused by coral mucus. Mar Ecol Prog Ser 307:69-84

> Iglesias-Prieto R, Matta JL, Robins WA, Trench RK (1992) Photosynthetic response to elevated-temperature in the symbiotic dinoflagellate Symbiodinium microadriaticum in culture. Proc Natl Acad Sci USA 89:10302-10305

Jackson JBC, Kirby MX, Berger WH, Bjorndal KA and others (2001) Historical overfishing and the recent collapse of coastal ecosystems. Science 293:629-637

Jordan TP, Merino M, Moreno O, Martin E (1981) Community structure of coral reefs in the Mexican Caribbean. Proc 4th Int Coral Reef Symp, Manila, 2:303-308

Kaldy JE, Onuf CP, Eldridge PM, Cifuentes LA (2002) Carbon budget for a subtropical seagrass dominated coastal lagoon: How important are seagrasses to total ecosystem net primary production? Estuaries 25:528-539

Kaldy JE, Eldridge PM, Cifuentes LA, Jones WB (2006) Utilization of DOC from seagrass rhizomes by sediment bacteria: ${ }^{13} \mathrm{C}$-tracer experiments and modelling. Mar Ecol Prog Ser 317:41-55

> Kendrick GA, Hegge BJ, Wyllie A, Davidson A, Lord DA (2000) Changes in seagrass cover on Success and Parmelia Banks, Western Australia between 1965 and 1995. Estuar Coast Shelf Sci 50:341-353

- Kirkman H, Reid DD (1979) A study of the role of the seagrass Posidonia australis in the carbon budget of an estuary. Aquat Bot 7:173-183

Kline DI, Kuntz NM, Breitbart M, Knowlton N, Rohwer F (2006) Role of elevated organic carbon levels and microbial activity in coral mortality. Mar Ecol Prog Ser 314: 119-125

Koh EG (1997) Do scleractinian corals engage in chemical warfare against microbes? J Chem Ecol 23:379-398

Krupp DA (1985) An immunochemical study of the mucus from the solitary coral Fungia scutaria (Scleractinia, Fungiidae). Bull Mar Sci 36:163-176

> Lapointe BE, Barile PJ, Littler MM, Littler DS, Bedford BJ, Gasque C (2005) Macroalgal blooms on southeast Florida coral reefs: I. Nutrient stoichiometry of the invasive green alga Codium isthmocladum in the wider Caribbean indicates nutrient enrichment. Harmful Algae 4:1092-1105

> Larkum AWD, Wood WF (1993) The effect of UV-B radiation on photosynthesis and respiration of phytoplankton, benthic macroalgae and seagrasses. Photosynth Res 36:17-23

Lesser MP (2004) Experimental biology of coral reef ecosystems. J Exp Mar Biol Ecol 300:217-252

Lesser MP, Shick JM (1989) Effects of irradiance and ultraviolet radiation on photoadaptation in the zooxanthellae of Aiptasia pallida: primary production, photoinhibition and enzymic defenses against oxygen toxicity. Mar Biol 102: 243-255

Lesser MP, Stochaj WR, Tapley DW, Shick JM (1990) Bleaching in coral reef anthozoans: effects of irradiance, ultraviolet radiation, and temperature on the activities of protective enzymes against active oxygen. Coral Reefs 8:225-232

Mari X, Rochelle-Newall E, Torréton J, Pringault O, Jouon A, Migon C (2007) Water residence time: a regulatory factor of the DOM to POM transfer efficiency. Limnol Oceanogr 52:808-819

Merino-Ibarra M, Otero-Dávalos L (1991) Atlas ambiental costero: Puerto Morelos, Quintana Roo. Centro de Investiga- 
ciones de Quintana Roo, Chetumal, Quintana Roo, Mexico Nagelkerken I, Dorenbosch M, Verberk WCEP, Cocheret de la Morinière E, van der Velde G (2000) Importance of shallow-water biotopes of a Caribbean bay for juvenile coral reef fishes: patterns in biotope association, community structure and spatial distribution. Mar Ecol Prog Ser 202: 175-192

Naumann MS, Niggl W, Laforsch C, Glaser C, Wild C (2009) Coral surface area quantification-evaluation of established methods by comparison with computer tomography. Coral Reefs 28:109-117

Naumann MS, Haas A, Struck U, Mayr C, el-Zibdah M, Wild C (2010) Organic matter release by the dominant hermatypic corals of the Northern Red Sea. Coral Reefs. doi: 10.1007/s00338-010-0612-7

Nienhuis PH (1992) Ecology of coastal lagoons in the Netherlands (Veerse Meer and Grevelingen). Vie Milieu 42:59-72

Niggl W, Glas M, Laforsch C, Mayr C, Wild C (2009) First evidence of coral bleaching stimulating organic matter release by reef corals. Proc 11th Int Coral Reef Symp, Ft. Lauderdale 1:905-911

Niggl W, Haas AF, Wild C (2010) Benthic community composition affects $\mathrm{O}_{2}$ availability and variability in a northern Red Sea fringing reef. Hydrobiologia 644:401-405

> Nilsson GE, Östlund-Nilsson S (2004) Hypoxia in paradise: widespread hypoxia tolerance in coral reef fishes. Proc Biol Sci 271:S30-S33

Odum EP (1971) Fundamentals of ecology. WB Saunders, Philadelphia, PA

Odum HT, Burkholder PR, Rivero J (1959) Measurements of productivity of turtle grass flats, reefs, and the Bahia Fosforescente of southern Puerto Rico. Publ Inst Mar Sci Univ Texas 6:159-170

Ogden JC, Zieman JC (1977) Ecological aspects of coral reefseagrass bed contacts in the Caribbean. Proc 3rd Int Coral Reef Symp, Miami, 1:377-382

Porter JW (1974) Zooplankton feeding by the Caribbean, reef-building coral Montastrea cavernosa. Proc 2nd Int Coral Reef Symp, Brisbane, 1:111-125

Raffaelli DG, Raven JA, Poole LJ (1998) Ecological impact of green macroalgal blooms. Oceanogr Mar Biol Annu Rev 36:97-125

Ritchie KB (2006) Regulation of microbial populations by coral surface mucus and mucus-associated bacteria. Mar Ecol Prog Ser 322:1-14

Ritchie KB, Smith GW (2004) Microbial communities of coral surface mucopolysaccharide layers. In: Rosenberg E, Loya Y (eds) Coral health and disease. Springer-Verlag, New York, NY, p 259-264

Rochelle-Newall EJ, Torréton JP, Mari X, Pringault O (2008) Phytoplankton-bacterioplankton coupling in a subtropical South Pacific coral reef lagoon. Aquat Microb Ecol 50: 221-229

Ruíz-Rentería F, van Tussenbroek BI, Jordan-Dahlgren E (1998) Puerto Morelos, Quintana Roo, Mexico. In: Kjerfve, B. (ed) Caricomp-Caribbean coral reef, seagrass and mangrove sites. Unesco, Paris, p 57-66

Sand-Jensen K, Borum J (1991) Interactions among phyto-

Editorial responsibility: Peter Edmunds,

Northridge, California, USA plankton, periphyton, and macrophytes in temperate freshwater and estuaries. Aquat Bot 41:137-175

Smith JE, Shaw M, Edwards RA, Obura D and others (2006) Indirect effects of algae on coral: algae-mediated, microbe-induced coral mortality. Ecol Lett 9:835-845

Sorokin YI (1973) On the feeding of some scleractinian corals with bacteria and dissolved organic matter. Limnol Oceanogr 18:380-385

Stephens GC (1962) Uptake of organic material by aquatic invertebrates. I. Uptake of glucose by the solitary coral Fungia scutaria. Biol Bull 123:648-657

Suchanek TH, Williams SL, Ogden JC, Hubbard DK, Gill IP (1985) Utilization of shallow-water seagrass detritus by Caribbean deep-sea macrofauna: delta super(13)C evidence. Deep-Sea Res 32:201-214

Tenore KR (1977) Growth of the polychaete, Capitella capitata, cultured on different levels of detritus derived from various sources. Limnol Oceanogr 22:936-942

Vacelet E, Thomassin B (1991) Microbial utilization of coral mucus in long term in situ incubation over a coral reef. Hydrobiologia 211:19-32

Valiela I (1984) Marine ecological processes. Springer-Verlag, New York, NY

Viaroli P, Bartoli M, Bondavalli C, Naldi M (1995) Oxygen fluxes and dystrophy in a coastal lagoon colonized by Ulva rigida (Sacca di Goro, Po River Delta, Northern Italy). Fresenius Environ Bull 4:381-386

Warner ME, Fitt WK, Schmidt GW (1996) The effects of elevated temperature on the photosynthetic efficiency of zooxanthellae in hospite from four different species of reef coral: a novel approach. Plant Cell Environ 19:291-299

Wild C, Rasheed M, Werner U, Franke U, Johnstone R, Huettel M (2004a) Degradation and mineralization of coral mucus in reef environments. Mar Ecol Prog Ser 267: $159-171$

> Wild C, Huettel M, Klueter A, Kremb SG, Rasheed M, Jørgensen BB (2004b) Coral mucus functions as an energy carrier and particle trap in the reef ecosystem. Nature 428 : $66-70$

Wild C, Rasheed M, Jantzen C, Cook P, Struck U, Huettel M, Boetius A (2005) Benthic metabolism and degradation of natural particulate organic matter in carbonate and silicate reef sands of the Northern Red Sea. Mar Ecol Prog Ser 298:69-87

Wild C, Haas A, Naumann M, Mayr C, el-Zibdah M (2009) Comparative investigation of organic matter release by corals and benthic reef algae-implications for pelagic and benthic microbial metabolism. Proc 11th Int Coral Reef Symp, Ft. Lauderdale 1:1319-1323

Williams SL (1987) Competition between the seagrasses Thalassia testudinum and Syringodium filiforme in a Caribbean lagoon. Mar Ecol Prog Ser 35:91-98

Ziegler S, Benner R (1999) Dissolved organic carbon cycling in a subtropical seagrass-dominated lagoon. Mar Ecol Prog Ser 180:149-160

Ziegler S, Benner R (2000) Effects of solar radiation on dissolved organic matter cycling in a subtropical seagrass meadow. Limnol Oceanogr 45:257-266

Submitted: February 10, 2010; Accepted: April 20, 2010

Proofs received from author(s): June 19, 2010 